Journal of Agricultural Sciences
(Tarim Bilimleri Dergisi)

\title{
Spectroscopic Characterisation and Elemental Composition of Biochars Obtained from Different Agricultural Wastes
}

\author{
Muhittin Onur AKCA $^{\mathrm{a}^{*} \mathbb{D}}$, Sonay SOZUDOGRU OK ${ }^{\mathrm{a}} \mathbb{D}^{\mathbb{D}}$, KIymet DENIZ $^{\mathrm{b}} \mathbb{D}^{\mathbb{D}}$, Abdoelbage MOHAMMEDELNOUR ${ }^{\mathrm{a}} \mathbb{D}^{\mathbb{D}}$, \\ Mumtaz KIBAR ${ }^{\mathbf{a}}$ iD

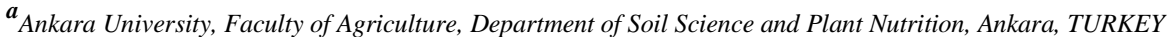

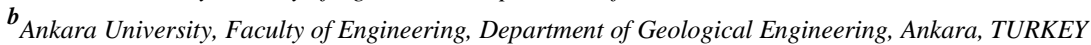

\section{ARTICLE INFO}

Research Article

Corresponding Author: Muhittin Onur AKCA, E-mail: moakca@ankara.edu.tr

Received: 25 September 2019 / Revised: 5 March 2020 / Accepted: 29 June 2020 / Online: 04 December 2021

\section{ABSTRACT}

The use of biochar (BC) has an environmental importance in terms of climate change, soil fertility, waste management and energy generation. The purpose of this study was to reveal some of the structural characteristics of $\mathrm{BC}$ produced from agricultural wastes by employing spectroscopic techniques within a short time frame. The BCs were produced via slow pyrolysis at $300{ }^{\circ} \mathrm{C}$ from four feedstocks: tea waste (TW), hazelnut husk $(\mathrm{HH})$, rice husk $(\mathrm{RH})$ and poultry litter $(\mathrm{PL})$. The $\mathrm{pH}$ of plant-derived $\mathrm{BC}$ was alkaline ( $\mathrm{pH}$ : 7-9), and the $\mathrm{pH}$ of manure-derived $\mathrm{BC}$ was strongly alkaline (pH: 10.1). PLBC has the highest $\left(4.67 \mathrm{dS} \mathrm{m}^{-1}\right)$ electrical conductivity (EC) when compared to other $\mathrm{BC}$ materials. According to the X-ray fluorescence (XRF) analysis method, organic compound contents of TWBC and HSBC were found to be higher than the other two BCs, while the other two BCs (RHBC and PLBC) were richer in mineral content. TWBC and HHBC were composed of more mineral elements when compared to RHBC and PLBC, but the latter two were still rich in minerals. The surface area of RHBC was found higher $\left(12.9 \mathrm{~m}^{2} \mathrm{~g}^{-1}\right)$ than other $\mathrm{BC}$ materials. According to the X-ray fluorescence (XRF) analysis method, the total element content of PLBC was found higher than the other BCs. In addition, the silicon (Si) content of RHBC was considerably higher (16.4\%). In PLBC's XRD diagram: quartz $\left(\mathrm{SiO}_{2}\right)$ at $3.41(\AA)$; calcite $\left(\mathrm{CaCO}_{3}\right)$ at $3.96,2.94$ and $1.91(\AA)$; sylvine $(\mathrm{KCl})$ at 3.06 and $1.85(\AA)$; and whitlockite $\left([\mathrm{Ca}, \mathrm{Mg}]_{3}\left[\mathrm{PO}_{4}\right]_{2}\right)$ at 2.78 and $2.17(\AA)$ were found. In HHBC and RHBC diagrams, partially crystallized carbon $(\mathrm{CryC})$ peaks were mainly observed between 1.20 and $2.34(\AA)$, and cristobalite peaks (i.e., amorphous $\mathrm{SiO}_{2}$ ) were observed at 3.91 and $3.40(\AA)$.

Keywords: Biochar, Plant nutrients, XRD and XRF Spectroscopy, Spectroscopic characterisation

(C) Ankara University, Faculty of Agriculture

\section{Introduction}

Biochar (BC) is a material that is produced as a result of the conversion of various wastes from agricultural, environmental or industrial sources into coal by heating them in an oxygen-free environment (i.e., by pyrolysis). Because the waste is burned in an oxygen-free environment, it becomes a solid material that contains a large amount of organic carbon (OC). Moreover, its $\mathrm{pH}$ can be either acidic or alkaline, it is porous, and it has a high adsorption capacity (Lehman et al. 2006; Chan et al. 2007; Verheijen et al. 2010). In addition to its improving effects on soil properties, BCs can reduce the negative effects of pesticides, heavy metals and hydrocarbons in soil (Ogawa et al. 2006; Glaser et al. 2009; Beesley et al. 2011; Cabrera et al. 2011; Tang et al. 2013).

Although there are many studies on various feedstocks and the BCs derived from these studies on different types of feedstocks, different pyrolysis conditions and different use areas of BCs are still ongoing in different countries (Enders et al. 2012; Ahmad et al. 2013; Zhao \& Nartey 2014; Prakongkep et al. 2015). Animal and plant wastes are often used as feedstocks in $\mathrm{BC}$ production. However, main chemical and structural properties of the biomass material can affect the composition of the obtained BC and, hence, its behaviour in soil (Downie et al. 2009). Lehmann \& Joseph (2015) suggested that BC was the best material for soil improvement when compared to other organic soil conditioners and the effects of organic soil conditioners were directly linked to their properties, such as their $\mathrm{pH}$, surface area, ash content and plant nutrient content.

The type and amount of materials that are used as feedstocks for BC production may vary depending on the country. Scott et al. (2014) indicated that since each feedstock contained different amount of nutrients, plants could have used them at different levels. Many studies have investigated the use of BC in different areas, other than for agricultural purposes, such as for water treatment, briquette making and energy production (Nakka 2015). Recent studies have shown that chemical methods for analysing BC are not preferred by researchers because they are both time consuming and costly; instead, because of recent technological developments, physical methods are increasingly preferred, as they are less costly and give quick results. For inert materials such as BC, more detailed and precise results are obtained by spectroscopic analyses methods. Recently, advanced 
spectroscopic techniques have been used to characterise BC (Igalavithana et al. 2017), such as the X-ray fluorescence (XRF) and $\mathrm{X}$-ray diffractometer (XRD) techniques, which had the lowest cost and user friendly. Hammes et al. (2007) listed several methods for BC characterisation, some of which are not only time consuming (about $24 \mathrm{~h}$ ) but also quite expensive. In addition, some of these methods consume a large amount of chemicals. Bellon-Maurel \& McBratney (2011) reviewed the pioneering studies on the adoption of spectroscopic techniques, which were found to be simpler and more cost-effective ways in which to measure BC characteristics.

The structure of BC derived from various feedstocks and similar feedstocks under different temperatures and duration may be different. For this reason, it is very important to determine the BC structures derived from different feedstocks that uses spectroscopic characterisation processes to obtain fast, practical and more accurate results. XRD and XRF spectroscopic techniques were used in this study. XRD analysis is advantageous for BC that has a high crystallinity because this analysis method provides both three-dimensional information (e.g., crystallite size and interlayer spacing) and information related to other characteristics of carbonaceous materials such as BC (Lehmann \& Joseph 2015). Minerals in feedstock mostly determine the ash fraction composition of $\mathrm{BC}$; however, most inorganic components do not volatilize at the temperature typically used in the pyrolysis process $\left(105^{\circ} \mathrm{C}\right)$. As such, one way of determining the elements that are present in $\mathrm{BC}$ and determining their quality is to use XRF spectroscopy. XRF analysis data is usually presented as the weight percentage of the most widely recognized elemental oxide. The structure of BC derived from the same feedstocks but in different countries may be different. For this reason, studying the $\mathrm{BC}$ characterisation data from different countries would be useful for researchers, as it would allow them to form a library of BC characteristics. The purpose of this study was to reveal some of the structural characteristics of BC produced from different types of agricultural wastes in a single country, using appropriate spectroscopic techniques to determine their general chemical composition in a short timeframe.

\section{Material and Methods}

\subsection{Materials}

This study was carried out to transform different agricultural wastes into BC and to determine the roles of these obtained BCs in agricultural sustainability using spectroscopic methods. The feedstocks were obtained from various regions in Turkey: tea waste, TW (Camellia sinensis L.) from the General Directorate of Tea Enterprises (CAYKUR); hazelnut husk, HH (Corylus avellana L.) from the Hazelnut Producers Union (PANKOBIRLIK); rice husks, RH (Oryza sativa L.) from a commercial enterprise in the Çorum Osmancık region; and poultry litter, PL from the Ankara University Research and Application Farm. After the feedstocks were sieved through a $0.5 \mathrm{~mm}$ sieve, they were dried in a $105^{\circ} \mathrm{C}$ oven for $24 \mathrm{~h}$ before pyrolysis and underwent slow pyrolysis in an electric oven at $300{ }^{\circ} \mathrm{C}$, in an oxygen-free environment. The temperature of the oven gradually changed from $10{ }^{\circ} \mathrm{C} \mathrm{d}^{-1}$ to $300{ }^{\circ} \mathrm{C} \mathrm{d}^{-1}$ within $2 \mathrm{~h}$, at which time BC production was completed. The BCs were prepared for analysis $10 \mathrm{~h}$ after pyrolysis was completed. The degree of mineral composition and crystallinity of the BCs were determined by XRD at the laboratories of the Earth Sciences Application and Research Centre (YEBIM) of Ankara University.

\subsection{Methods}

According to Rajkovich et al. (2012), the pH of the BCs was measured (1:20 water suspension) with a pH meter (Mettler Toledo, FP20), and the electrical conductivity (EC) was measured (1:20 water suspension) with an EC meter (Consort, C 3010). According to ASTM (2007), the ash and organic matter (OM) content of the BCs were determined by incineration at $550{ }^{\circ} \mathrm{C}$. The total nitrogen $(\mathrm{N})$ content of BCs was determined using the Kjeldahl method (Bremner 1965), the total potassium (K) content was determined using flame photometry (Rayment \& Higginson 1992) and the total phosphorus (P) content was determined using the yellow vanadomolybdophosphoric acid method (Kuo 1996). The surface area was measured on a surface analyser (Nova, Quantachrome Instruments) at $77 \mathrm{~K}$, while the N sorption was determined using the Brunauer-Emmett-Teller (BET) equation (Brunauer et al. 1938).

Multi-element concentration was determined using polarised energy-dispersive XRF (PED-XRF; Spectro XLAB 2000). A total of $4 \mathrm{~g}$ of powdered BC samples were mixed with $0.9 \mathrm{~g}$ of wachs, which was used as a blinder, and the mixture was pressed at $20 \mathrm{~N}$ in an automatic press machine to get a $32 \mathrm{~mm}$ diameter pressed-disc pellet (Koralay 2010). Wachs is a type of alkane paraffin that contains hydrocarbons $(\mathrm{CH})$, meaning that the wachs has an organic chemical composition and does not contain any inorganic content. The author who used the PED-XRF spectrometer also separately analysed the wachs alone and the sample combined with the wachs. In this way, it was possible to see that the wachs did not change the chemical composition of the samples.

The spectrometer was equipped with a $400 \mathrm{~W}$ rhodium $(\mathrm{Rh})$ anode $\mathrm{X}$-ray tube and a $0.5 \mathrm{~mm}$ beryllium (Be) side window. The detector in the spectrometer was silicon ( $\mathrm{Si}$; lithium [Li]), with cooled liquid $\mathrm{N}_{2}$ and a resolution of $<150 \mathrm{eV}$ at $\mathrm{Mn} \mathrm{Ka}$, 5000 cps (Kadığlu et al. 2009; Güllü \& Kadığlu 2017). Diffraction patterns were collected with an Inel Equinox 1000 instrument that was equipped with a cobalt $(\mathrm{Co})$ tube at a wavelength of $\lambda=1.788970 \AA$ and a $120^{\circ}$ curved position-sensitive detector (CPS-120). The data was converted to numeric values relevant to a copper $(\mathrm{Cu})$ cathode $(\lambda=1.541874 \AA)$ for an easy evaluation. The raw data was smoothed, and the baseline was corrected. 


\section{Results and Discussion}

\subsection{Properties of the materials}

General properties of the feedstocks and BC materials are shown in Table 1 and Table 2. In terms of the general properties of the feedstocks, it was seen that the highest $\mathrm{pH}$ occurred in rice husk $(\mathrm{RH})$ and the lowest in tea waste (TW), while the highest EC value was found in poultry litter (PL) and the lowest in rice husk (RH). As for the organic matter (OM) content, the highest value was seen in TW and the lowest in RH, while the highest value for N content was in PL and the lowest in RH. It was further found that the highest P value was in PL and the lowest in HH, while the highest K value was in PL and the lowest in TW.

Table 1- General properties of the feedstocks

\begin{tabular}{cccccccc}
\hline $\begin{array}{c}\text { Raw } \\
\text { materials }\end{array}$ & $\begin{array}{c}p H \\
\left(w v^{-1}\right)\end{array}$ & $\begin{array}{c}E C \\
\left(d S m^{-1}\right)\end{array}$ & $\begin{array}{c}\text { OM } \\
(\%)\end{array}$ & $\begin{array}{c}\text { Org } \\
(\%)\end{array}$ & $\begin{array}{c}N \\
(\%)\end{array}$ & $\begin{array}{c}P \\
(\%)\end{array}$ & $\begin{array}{c}K \\
(\%)\end{array}$ \\
\hline TW & 5.22 & 1.17 & 96.3 & 55.9 & 3.19 & 0.33 & 0.82 \\
HH & 5.75 & 1.90 & 94.6 & 54.9 & 2.94 & 0.16 & 0.93 \\
RH & 7.24 & 0.48 & 56.4 & 32.8 & 0.92 & 0.36 & 1.35 \\
PL & 7.31 & 3.88 & 78.0 & 45.2 & 4.33 & 0.84 & 4.83 \\
\hline
\end{tabular}

TW: Tea waste; HH: Hazelnut husk; RH: Rice husk; PL: Poultry litter

BC derived from plant wastes (i.e., [TWBC], [HHBC] and [RHBC]) showed neutral or low alkalinity pH, with no salinity problem, while the $\mathrm{pH}$ value of $\mathrm{BC}$ derived from animal waste (i.e., [PLBC]) was found to have strong alkalinity (pH: 10.1) and to had salinity (Table 2). The EC value of PLBC $\left(4.67 \mathrm{dS} \mathrm{m}^{-1}\right)$ was 6 to 11 times higher than that of the other BCs. Past studies have reported that the EC value of PLBC is generally higher than those of other plant-derived BCs, with values varied from 5.66 $\mathrm{dS} \mathrm{m}^{-1}$ to $33.7 \mathrm{dS} \mathrm{m}^{-1}$ (Evans et al. 2017; Clemente et al. 2018). The high EC value indicates that PLBC is more readily soluble, to some extent, than are other BCs.

The high $\mathrm{pH}, \mathrm{EC}$ and organic C values of PLBC are compatible with the results of a study by Sikder \& Joardar (2019). It was also stated in previous studies that the $\mathrm{pH}$, salinity and $\mathrm{N}$ values of animal-derived BCs are higher than those of plant-derived BCs (Scott 2014 et al; Jassal et al. 2015). It is possible to get an idea of the mineral matter contained in BC by reviewing its ash content. Higher ash content was detected in the samples of plant-derived RHBC (33.81\%) and animal-derived PLBC (33.83\%) than was detected in the other samples, indicating that RHBC and PLBC had a higher mineral content. The ash content of TWBC $(7.96 \%)$ and $\mathrm{HHBC}(5.51 \%)$ were quite low. A comparison of the raw and BC materials showed that the $\mathrm{pH}$ of all materials increased after the $\mathrm{BC}$ creation process, while the $\mathrm{N}, \mathrm{pH}$ and $\mathrm{K}$ values decreased. The high mineral content in all the $\mathrm{BCs}$ indicated that these materials were rich in various elements including plant nutrients. However, when the XRD results were analysed, it was seen that these BCs contained different mineral substances. For example, PLBC contained minerals such as sylvine $(\mathrm{KCl})$ and calcite $\left(\mathrm{CaCO}_{3}\right)$, while RHBC contained cristobalite $\left(\mathrm{SiO}_{2}\right)$, which could be a result of Si rather than plant nutrients. The mineral content levels were much lower (mostly below 20\%) in BCs derived from plant residues than the animalderived BC (Zhao et al. 2013). Some research revealed that, according to data through various processes (including slow pyrolysis), BC derived from PL had the highest ash content (Field et al. 2013; Qambrani et al. 2017). Conversely, the ash content of BCs derived from wood was low $(<10 \%)$. Products with ash content is greater than $50 \%$ are included under the category of pyrogenic carbonaceous material and are not considered BCs (European Biochar Certificate [EBC] 2015).

Table 2- Physicochemical properties of the BCs

\begin{tabular}{ccccccccccc}
\hline BC materials & $\begin{array}{c}p H \\
\left(w v^{-1}\right)\end{array}$ & $\begin{array}{c}E C \\
\left(d S m^{-1}\right)\end{array}$ & $\begin{array}{c}\text { Ash } \\
(\%)\end{array}$ & $\begin{array}{c}\text { OM } \\
(\%)\end{array}$ & $\begin{array}{c}\text { Org } C \\
(\%)\end{array}$ & $C: N$ & $\begin{array}{c}N \\
(\%)\end{array}$ & $\begin{array}{c}P \\
(\%)\end{array}$ & $\begin{array}{c}K \\
(\%)\end{array}$ & $\begin{array}{c}\text { Specific surface area } \\
\left(\mathrm{m}^{2} \mathrm{~g}^{-1}\right)\end{array}$ \\
\hline TWBC & 7.42 & 0.78 & 7.96 & 92.1 & 53.5 & 22.2 & 2.40 & 0.04 & 0.30 & 8.26 \\
HHBC & 7.33 & 0.42 & 5.51 & 94.5 & 54.9 & 77.3 & 0.71 & 0.03 & 0.10 \\
RHBC & 7.93 & 0.74 & 33.8 & 66.2 & 38.5 & 47.6 & 0.81 & 0.08 & 0.22 & 3.68 \\
PLBC & 10.1 & 4.67 & 33.8 & 66.2 & 38.5 & 9.08 & 4.24 & 0.09 & 0.40 \\
\hline
\end{tabular}

TWBC: Tea waste biochar; HHBC: Hazelnut husk biochar, RHBC: Rice husk biochar; PLBC: Poultry litter biochar

Black color was dominant in the BC samples obtained in this study. Armynah et al. (2018) pointed out that the colour of samples is related to the ash content. There was also a high ash content in grey BC samples. It was thought that the ash contents of PLBC and RHBC BCs were higher than those of the others because of the presence of calcite $\left(\mathrm{CaCO}_{3}\right)$ and quartz $\left(\mathrm{SiO}_{2}\right)$. These results are consistent with the XRD results. PLBC was similar to RHBC in terms of its organic matter (OM) and ash content levels (\%). TWBC and HHBC had high levels of organic compounds, while RHBC and PLBC were found to be rich in terms of mineral content (Table 2). This may be due to the volatility of the OM in the plant-based feedstocks, such as the easily decomposable organic $\mathrm{C}$ found in TW and HH. This is followed by TWBC, RHBC and HHBC, respectively. The total N value of TWBC was higher than that of the other plant-derived BCs; this can be attributed to the higher content of green plant parts 
found in the feedstock, as the tea is grown in humid regions and is a shrub plant. The $\mathrm{N}$ values of the other two plant-derived BCs were quite low.

PLBC and TWBC had the highest $\mathrm{N}$ contents of the BC materials studied (Table 2). However, when comparing these to the $\mathrm{N}$ contents of the feedstocks, their $\mathrm{N}$ contents before being processed into BCs were greater. In other words, the $\mathrm{N}$ contents of the materials decreased through the BC process. A transition in the chemical structure of the remaining $\mathrm{N}$ in the $\mathrm{BC}$ also occurred following the loss of $\mathrm{N}$ at higher temperatures. The volatilisation of most $\mathrm{N}$ and sulphur $(\mathrm{S})$ compounds occurs above $200{ }^{\circ} \mathrm{C}$ and $375^{\circ} \mathrm{C}$, respectively, whereas the volatilisation of $\mathrm{K}$ and $\mathrm{P}$ occurs between $700{ }^{\circ} \mathrm{C}$ and $800{ }^{\circ} \mathrm{C}$, respectively (DeLuca 2009 ). The amount of K in TWBC was found higher than the other plant-derived BCs. Scott et al. (2014) stated that plant-derived BC contains lower levels of $\mathrm{N}$ and $\mathrm{P}$ than does animal-derived $\mathrm{BC}$ and that the nutrition content of plant-derived $\mathrm{BC}$ is not high enough to allow it to be used for fertilisation.

In the current study, the highest surface area among the samples was found to occur in RHBC $\left(12.9 \mathrm{~m}^{2} \mathrm{~g}^{-1}\right)$. Wang et al. (2018) stated that Si content-rich BCs have a porous structure after Si release. In the present study, the surface area values of TWBC and PLBC were similar (8.26 and $\left.7.36 \mathrm{~m}^{2} \mathrm{~g}^{-1}\right)$, while the lowest surface area was found in HHBC $\left(3.68 \mathrm{~m}^{2} \mathrm{~g}^{-1}\right)$. Fang and $\mathrm{Xu}$ (2014) reported that $26.7 \%$ of BC samples derived from hazelnut shells are made of cellulose, $30.29 \%$ of hemicellulose and $43.01 \%$ of lignin. Thus, it was assumed that the low surface area of HHBC was due to the fact that it had more lignin in it than did the other BCs. Among other feedstocks, a more C-rich BC can be derived from woody biomass, which can have different amounts of lignin, cellulose and hemicellulose but which has small amounts of other inorganic compounds and organic extractives (Suliman et al. 2016). Xu \& Chen (2013) found that the higher the content of lignin and minerals a woody biomass has, the more BC it can produce. Hence, woody biomass is one of the most important sources of BC. The dynamic degradation of organic materials and vascular bundles, and the formation of channel structures that occurs during pyrolysis, may cause a rise in the outer area and pore volumes of BC (Kim et al. 2013; Li et al. 2013). BC derived from rice straw is different from that derived from other feedstocks, as it has a low amount of lignin and a high amount of Si and K (Bourke et al. 2007; Keiluweit et al. 2010). The most important contrasts between a biomass and the BC derived from it are the surface area, pore structure (i.e., micropores, mesopores and macropores) and physicochemical properties such as composition, elemental makeup and ash content. In all cases, however, BCs contain more ash and carbon than do raw samples (Apaydın-Varol \& Pütün 2012).

\subsection{XRF spectroscopy}

In terms of the total element content of the BC samples, as determined by XRF, the PLBC was the richest in terms of mineral contents (Table 4). In general, the plant-derived BCs had a much less favourable nutrient content than the animal-derived BC. The ratios of $\mathrm{C} / \mathrm{P}$ and $\mathrm{C} / \mathrm{N}$ of most wood-based and nut-based $\mathrm{BCs}$ are remarkably high. On the contrary, these ratios were much lower in BCs derived from manure, crop and food waste. BCs derived from manure were the most nutrient-rich, particularly in terms of $\mathrm{C}$ and P. Condensed wood-derived BCs were often the most nutrient- and ash-rich, as this material was C-rich (Singh et al. 2010).

The nutrient content of a $\mathrm{BC}$ is highly dependent on the type of material used as a feedstock. For example, the $\mathrm{N}$ and $\mathrm{P}$ content is usually highest in manure-derived BCs, followed by those derived from grass and wood; however, the C content is usually higher in wood-derived BCs, than that of grass- and manure-derived BCs (El-Naggar et al. 2019). The total element content of a BC does not always reflect the amount of plant nutrients available for plant growth, as this also depends on the pyrolysis temperature (Gunarathne et al. 2017). Elements such as calcium (Ca) and strontium (Sr) sometimes occur in PLBC as a result of some of the minerals included in feed. For example, various minerals, such as limestone and zeolite, are added to feeds to meet the nutritional needs of the chickens (Bintaş 2014); because the digestive system of chickens is weak, toxic elements (e.g., tin $[\mathrm{Sn}]$, lead $[\mathrm{Pb}], \mathrm{Cu}$, zinc $[\mathrm{Zn}]$, chromium $[\mathrm{Cr}]$ and iron $[\mathrm{Fe}]$ ) that are difficult to digest are thrown out directly in the faeces.

$\mathrm{Si}$ is the most abundant element in soil, so all plants have different amounts of Si in their tissues, depending on the species. Rice is known to absorb more Si from the soil, for metabolic activities, than does any other plant, which explains the high Si content of RHBC (16.4\%) found in this study. The Si content of the plants varies from $0.1 \%$ to $10 \%$, depending on the species (Tamai \& Feng Ma 2003). While some plants contain $1 \%$ to $2 \%$ Si (dry matter), rice (including the stem and leaves) contains $10 \%$ to $20 \% \mathrm{Si}$. RHs are composed of ash, Si and C, with Si protecting the plant's C from degrading via encapsulation (Wilding et al. 1967). The sulphur (S) content of all the BCs were found to be low, as $\mathrm{C}, \mathrm{N}$ and S evaporate with increasing temperatures; however, micronutrients have been reported to increase their availability due to low evaporation (Chan \& Xu 2009).

In their study on BCs produced from 14 waste materials, Prakongkep et al. (2015) stated that plant nutrients mostly form in crystalline minerals on the surface or cell structures of BCs. In the present study, the most significant difference in the microelements of the four BCs was observed in relation to $\mathrm{Zn}$ and $\mathrm{Cu}$ (Table 4); although the $\mathrm{Zn}$ and $\mathrm{Cu}$ contents of the other BCs were not very low, the $\mathrm{Zn}\left(1098 \mathrm{mg} \mathrm{kg}^{-1}\right)$ and $\mathrm{Cu}\left(206.9 \mathrm{mg} \mathrm{kg}^{-1}\right)$ contents of PLBC were 14-28 times and 8-17 times higher than those of the other BCs, respectively. 
During the XRF measurements, each sample was measured three times, and the average of the measurements was given as the result. The spectrometer was calibrated using two standard rocks, G01-GSD-09 and K04-NIST-2704, based on the certificated concentrations of the elements under investigation (Table 3). The standard samples were run through the spectrometer on a different date for a full analysis, and the concentrations of the elements measured this time are shown in Table 3. XRF data is more reliable than is experimental data because of the use of a standard reference material for the measurements and integration of the calculations.

Table 3- The concentration of certificated elements in the standard rocks used in the PED-XRF analysis for calibration of the spectrometer, and the concentration of standard sediments measured by PED-XRF in the main analysis

\begin{tabular}{|c|c|c|c|c|c|}
\hline Elements & Unit & $\begin{array}{c}\text { Certificated } \\
\text { concentration } \\
\text { G01-GSD-09 } \\
\text { (Sediment) }\end{array}$ & $\begin{array}{c}\text { Measured } \\
\text { concentration } \\
\text { G01-GSD-09 } \\
\text { (Sediment) }\end{array}$ & $\begin{array}{c}\text { Certificated } \\
\text { concentration } \\
\text { K04-NIST-2704 } \\
\text { (River Sediment) }\end{array}$ & $\begin{array}{c}\text { Measured } \\
\text { concentration } \\
\text { K04-NIST-2704 } \\
\text { (River Sediment) }\end{array}$ \\
\hline $\mathrm{Na}$ & $\%$ & $0.755 \pm 0.084$ & 0.79 & $0.201 \pm 0.076$ & 0.36 \\
\hline $\mathrm{Mg}$ & $\%$ & $1.824 \pm 0.024$ & 1.76 & $1.369 \pm 0.022$ & 1.98 \\
\hline $\mathrm{Al}$ & $\%$ & $5.972 \pm 0.018$ & 5.10 & $7.006 \pm 0.02$ & 8.26 \\
\hline $\mathrm{Si}$ & $\%$ & $28.17 \pm 0.03$ & 27.98 & $25.78 \pm 0.03$ & 26.28 \\
\hline $\mathrm{P}$ & $\%$ & $0.0853 \pm 0.0013$ & 0.091 & $0.1274 \pm 0.0014$ & 0.23 \\
\hline S & $\mu \mathrm{g} \mathrm{g}^{-1}$ & $365 \pm 4.4$ & 371 & $4116 \pm 16$ & 4287 \\
\hline $\mathrm{Cl}$ & $\mu \mathrm{g} \mathrm{g}^{-1}$ & $95.6 \pm 1.2$ & 92.87 & $186.6 \pm 2$ & 191 \\
\hline $\mathrm{K}$ & $\%$ & $1.744 \pm 0.004$ & 1.65 & $2.152 \pm 0.004$ & 2.95 \\
\hline $\mathrm{Ca}$ & $\%$ & $4.252 \pm 0.006$ & 4.65 & $2.739 \pm 0.004$ & 3.10 \\
\hline $\mathrm{Ti}$ & $\%$ & $0.5349 \pm 0.0013$ & 0.43 & $0.4629 \pm 0.0012$ & 0.52 \\
\hline V & $\mu \mathrm{g} \mathrm{g}^{-1}$ & $93.7 \pm 4.3$ & 92.76 & $104.6 \pm 4$ & 106.20 \\
\hline $\mathrm{Cr}$ & $\mu \mathrm{g} \mathrm{g}^{-1}$ & $162.7 \pm 1.5$ & 160.72 & $177.1 \pm 1.4$ & 171.26 \\
\hline $\mathrm{Mn}$ & $\%$ & $0.06287 \pm 0.00024$ & 0.072 & $0.06069 \pm 0.00022$ & 0.0762 \\
\hline $\mathrm{Fe}$ & $\%$ & $3.528 \pm 0.005$ & 3.80 & $4.277 \pm 0.006$ & 5.72 \\
\hline $\mathrm{Co}$ & $\mu \mathrm{g} \mathrm{g}^{-1}$ & $13.9 \pm 1.9$ & 14.82 & $27.1 \pm 2.7$ & 28.22 \\
\hline $\mathrm{Ni}$ & $\mu \mathrm{g} \mathrm{g}^{-1}$ & $33.4 \pm 1.1$ & 34.27 & $44.5 \pm 1.2$ & 45.29 \\
\hline $\mathrm{Cu}$ & $\mu \mathrm{g} \mathrm{g}^{-1}$ & $36 \pm 0.9$ & 35.72 & $100 \pm 1.4$ & 102.21 \\
\hline $\mathrm{Zn}$ & $\mu \mathrm{g} \mathrm{g}^{-1}$ & $71.8 \pm 1$ & 70.65 & $422.5 \pm v$ & 430 \\
\hline $\mathrm{Ge}$ & $\mu \mathrm{g} \mathrm{g}^{-1}$ & $1.4 \pm 0.3$ & 1.22 & $2 \pm 0.3$ & 2.77 \\
\hline As & $\mu \mathrm{g} \mathrm{g}^{-1}$ & $10.3 \pm 0.5$ & 9.82 & $23.5 \pm 1.1$ & 25.76 \\
\hline $\mathrm{Se}$ & $\mu \mathrm{g} \mathrm{g}^{-1}$ & $0.3 \pm 02$ & 0.1 & $0.5 \pm 0.2$ & 0.9 \\
\hline $\mathrm{Br}$ & $\mu \mathrm{g} \mathrm{g}^{-1}$ & $0.8 \pm 0.2$ & 0.92 & $6.1 \pm 0.2$ & 8.62 \\
\hline $\mathrm{Rb}$ & $\mu \mathrm{g} \mathrm{g}^{-1}$ & $80.6 \pm 0.4$ & 78.92 & $100.8 \pm 0.5$ & 103.71 \\
\hline $\mathrm{Sr}$ & $\mu \mathrm{g} \mathrm{g}^{-1}$ & $166.1 \pm 0.6$ & 168.21 & $128.6 \pm 0.5$ & 131.23 \\
\hline $\mathrm{Y}$ & $\mu \mathrm{g} \mathrm{g}^{-1}$ & $26.3 \pm 0.4$ & 27.87 & $30.5 \pm 0.4$ & 32.82 \\
\hline $\mathrm{Zr}$ & $\mu \mathrm{g} \mathrm{g}^{-1}$ & $381 \pm 0.9$ & 376.23 & $281.9 \pm 0.7$ & 287.5 \\
\hline $\mathrm{Nb}$ & $\mu \mathrm{g} \mathrm{g}^{-1}$ & $15.5 \pm 0.2$ & 14.22 & $12.8 \pm 0.2$ & 13.77 \\
\hline Mo & $\mu \mathrm{g} \mathrm{g}^{-1}$ & $1.2 \pm 0.2$ & 1.67 & $4.7 \pm 0.2$ & 5.90 \\
\hline $\mathrm{Cd}$ & $\mu \mathrm{g} \mathrm{g}^{-1}$ & $0.5 \pm 0$ & 0.4 & $2.9 \pm 0.2$ & 3.98 \\
\hline In & $\mu \mathrm{g} \mathrm{g}^{-1}$ & $0.7 \pm-0.4$ & 0.62 & $0.7 \pm 0$ & 0.21 \\
\hline Sn & $\mu \mathrm{g} \mathrm{g}^{-1}$ & $3.1 \pm 0.1$ & 3.98 & $9.6 \pm 0.2$ & 11.62 \\
\hline $\mathrm{Sb}$ & $\mu \mathrm{g} \mathrm{g}^{-1}$ & $1 \pm 0.1$ & 1.77 & $3.7 \pm 0.2$ & 4.66 \\
\hline $\mathrm{Te}$ & $\mu \mathrm{g} \mathrm{g}^{-1}$ & $1.2 \pm 0$ & 1.90 & $1.2 \pm 0$ & 1.87 \\
\hline I & $\mu \mathrm{g} \mathrm{g}^{-1}$ & $1.4 \pm 0.4$ & 1.0 & $1.3 \pm 0.4$ & 1.90 \\
\hline Cs & $\mu \mathrm{g} \mathrm{g}^{-1}$ & $7.1 \pm 0.5$ & 6.12 & $5.2 \pm 0.5$ & 7.72 \\
\hline $\mathrm{Ba}$ & $\mu \mathrm{g} \mathrm{g}^{-1}$ & $430.1 \pm 1.5$ & 439 & $421.6 \pm 1.5$ & 430.23 \\
\hline $\mathrm{La}$ & $\mu \mathrm{g} \mathrm{g}^{-1}$ & $42.3 \pm 1.3$ & 45.43 & $29.5 \pm 1.3$ & 31.43 \\
\hline $\mathrm{Ce}$ & $\mu \mathrm{g} \mathrm{g}^{-1}$ & $81.4 \pm 1.7$ & 83.87 & $58.6 \pm 1.7$ & 60.9 \\
\hline $\mathrm{Nd}$ & $\mu \mathrm{g} \mathrm{g}^{-1}$ & $43.9 \pm 2.9$ & 44.93 & $27.6 \pm 2.7$ & 28.40 \\
\hline $\mathrm{Hf}$ & $\mu \mathrm{g} \mathrm{g}^{-1}$ & $7 \pm 1.8$ & 6.73 & $9.5 \pm 2.3$ & 11.04 \\
\hline $\mathrm{Ta}$ & $\mu \mathrm{g} \mathrm{g}^{-1}$ & $5.8 \pm-5$ & 5.44 & $8.0 \pm-5.2$ & 9.10 \\
\hline $\mathrm{W}$ & $\mu \mathrm{g} \mathrm{g}^{-1}$ & $2.7 \pm 0$ & 2.1 & $4.2 \pm-2.4$ & 5.62 \\
\hline $\mathrm{Hg}$ & $\mu \mathrm{g} \mathrm{g}^{-1}$ & $0.8 \pm 0$ & 0.98 & $0.7 \pm 0.4$ & 0.4 \\
\hline $\mathrm{Pb}$ & $\mu \mathrm{g} \mathrm{g}^{-1}$ & $22.9 \pm 0.6$ & 22.83 & $157.8 \pm 1.2$ & 167 \\
\hline $\mathrm{Bi}$ & $\mu \mathrm{g} \mathrm{g}^{-1}$ & $0.7 \pm 0$ & 0.63 & $0.9 \pm 0$ & 0.54 \\
\hline Th & $\mu \mathrm{g} \mathrm{g}^{-1}$ & $13.3 \pm 0.5$ & 14.76 & $11.4 \pm 0.6$ & 9.72 \\
\hline $\mathrm{U}$ & $\mu \mathrm{g} \mathrm{g}^{-1}$ & $2.5 \pm 0.8$ & 13.11 & $2.8 \pm 0.9$ & 3.30 \\
\hline
\end{tabular}

In Table 4, it can be seen that, according to XRF analysis, the cobalt (Co) and molybdenum (Mo) contents of the BCs were also relatively high, and that $\mathrm{Sr}$ and $\mathrm{Sn}$ were more commonly observed than were other elements. These elements are essential microelements in terms of plant nutrition; however, soil contamination can occur when large amounts of them are incorporated into soil. 
Table 4- Total element contents of BCs determined by XRF

\begin{tabular}{|c|c|c|c|c|}
\hline Compounds & $T W B C$ & $H H B C$ & RHBC & $P L B C$ \\
\hline \multicolumn{5}{|c|}{$(\%)$} \\
\hline $\mathrm{Na}$ & 0.02 & 0.03 & 0.03 & 0.70 \\
\hline $\mathrm{Mg}$ & 0.22 & 0.23 & 0.33 & 1.39 \\
\hline $\mathrm{Al}$ & 0.25 & 0.22 & 0.00 & 0.27 \\
\hline $\mathrm{Si}$ & 0.56 & 0.73 & 16.4 & 1.24 \\
\hline $\mathrm{P}$ & 0.30 & 0.11 & 0.24 & 2.44 \\
\hline $\mathrm{S}$ & 0.26 & 0.16 & 0.30 & 1.35 \\
\hline $\mathrm{Cl}$ & 0.06 & 0.17 & 0.01 & 0.39 \\
\hline $\mathrm{K}$ & 2.93 & 1.38 & 2.13 & 8.66 \\
\hline $\mathrm{Ca}$ & 0.65 & 2.42 & 0.57 & 5.29 \\
\hline $\mathrm{Fe}$ & 0.05 & 0.21 & 0.43 & 0.52 \\
\hline $\mathrm{Ti}$ & 0.005 & 0.02 & 0.01 & 0.02 \\
\hline V & 0.0008 & 0.0008 & 0.0003 & 0.005 \\
\hline $\mathrm{Cr}$ & 0.0006 & 0.001 & 0.001 & 0.003 \\
\hline $\mathrm{Mn}$ & 0.16 & 0.03 & 0.03 & 0.12 \\
\hline Elements & \multicolumn{4}{|c|}{$\left(m g k g^{-1}\right)$} \\
\hline $\mathrm{Co}$ & 4.10 & 4.00 & 8.10 & 14.0 \\
\hline $\mathrm{Ni}$ & 10.4 & 12.1 & 6.50 & 37.7 \\
\hline $\mathrm{Cu}$ & 25,4 & 25.9 & 12.4 & 206.9 \\
\hline $\mathrm{Zn}$ & 37.1 & 46.3 & 78.3 & 1098 \\
\hline $\mathrm{Ge}$ & 0.10 & 0.20 & 0.20 & 0.40 \\
\hline As & 0.20 & 2.80 & 2.10 & 1.50 \\
\hline $\mathrm{Se}$ & 1.00 & 1.00 & 0.10 & 1.10 \\
\hline $\mathrm{Sr}$ & 43.0 & 71.0 & 27.7 & 124.8 \\
\hline Mo & 1.00 & 1.60 & 1.50 & 9.70 \\
\hline $\mathrm{Cd}$ & 0.50 & 0.60 & 0.60 & 1.80 \\
\hline $\mathrm{Sn}$ & 53.0 & 55.8 & 4.7 & 148.2 \\
\hline I & 1.60 & 2.20 & 1.80 & 11.7 \\
\hline $\mathrm{Ba}$ & 48.2 & 68.8 & 21.7 & 89,5 \\
\hline $\mathrm{Hg}$ & 0.30 & 0.30 & 0.40 & 0.50 \\
\hline $\mathrm{Pb}$ & 1.30 & 4.40 & 2.20 & 5.90 \\
\hline $\mathrm{U}$ & 2.40 & 4.00 & 1.40 & 1.90 \\
\hline $\mathrm{Ga}$ & 0.5 & 0.8 & 0.3 & 0.6 \\
\hline $\mathrm{Br}$ & 6.3 & 1.3 & 8.8 & 25 \\
\hline $\mathrm{Rb}$ & 40.7 & 15.6 & 8.8 & 52.6 \\
\hline $\mathrm{Y}$ & 0.3 & 0.3 & 0.3 & 0.4 \\
\hline $\mathrm{Zr}$ & 1.7 & 11.1 & 4.1 & 4.5 \\
\hline $\mathrm{Nb}$ & 1 & 2.1 & 1.6 & 3.9 \\
\hline $\mathrm{Ag}$ & $<0.1$ & $<0.1$ & $<0.1$ & 0.9 \\
\hline In & 0.5 & 0.7 & 0.6 & 0.8 \\
\hline $\mathrm{Sb}$ & 0.6 & 0.8 & 0.7 & 0.8 \\
\hline $\mathrm{Te}$ & 0.8 & 1.4 & 1 & 1 \\
\hline $\mathrm{Cs}$ & 4 & 3.8 & 3.2 & 3.2 \\
\hline $\mathrm{La}$ & 5.4 & 21.5 & 7 & 6.7 \\
\hline $\mathrm{Ce}$ & 8.3 & 15.7 & 9.7 & 13.1 \\
\hline Hf & 1.6 & 1.8 & 1.2 & 6.7 \\
\hline $\mathrm{Ta}$ & 1.8 & 2 & 1.8 & 12.7 \\
\hline W & 1.3 & 1.5 & 1.9 & 5.7 \\
\hline $\mathrm{Tl}$ & 2 & 0.3 & 0.3 & 0.5 \\
\hline $\mathrm{Bi}$ & 0.3 & 2 & 0.3 & 0.4 \\
\hline Th & 0.3 & 0.1 & 0.4 & 0.4 \\
\hline
\end{tabular}

TWBC: Tea waste biochar; HHBC: Hazelnut husk biochar, RHBC: Rice husk biochar; PLBC: Poultry litter biochar

\subsection{XRD analysis}

The diagrams obtained from an XRD analysis of the BCs revealed amorphous crystalline structures (Figure 1). 


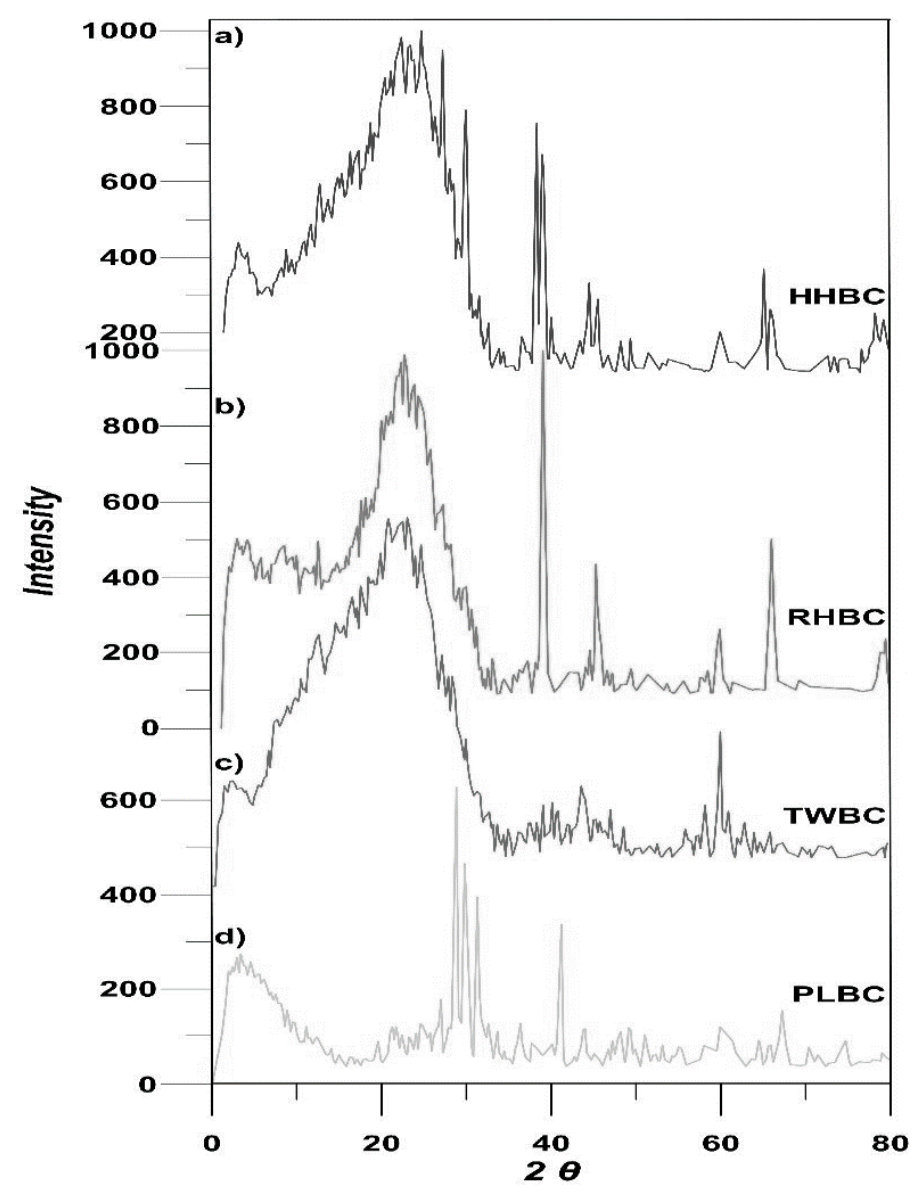

a) HHBC: Hazelnut husk biochar; b) RHBC: Rice husk biochar; c) TWBC: Tea waste biochar; d) PLBC: Poultry litter biochar

\section{Figure 1- XRD diagrams of the BCs}

The minerals seen in the PLBC diagrams were as follows: quartz $\left(\mathrm{SiO}_{2}\right)$ in $3.41(\AA)$; calcite $\left(\mathrm{CaCO}_{3}\right)$ in $3.96,2.94$ and 1.91 $(\AA)$; sylvine $(\mathrm{KCl})$ in 3.06 and $1.85(\AA)$; and whitlockite $\left([\mathrm{Ca}, \mathrm{Mg}]_{3}\left[\mathrm{PO}_{4}\right]_{2}\right)$ in 2.78 and 2.17 ( $\AA$ ) (Table 5). Table 5 shows the overall mineralogical composition of the BCs. Besides existing minerals, the presence of amorphous $\mathrm{C}$ and amorphous $\mathrm{Si}$ was also noteworthy. According to the results of the XRD analysis of the BCs, amorphous $\mathrm{C}$ content was determined elementally with minerals such as quartz, cristobalite, calcite, sylvine and whitlockite. The chemical compositions in the detected minerals also improve the chemical and physical structure of the soil in terms of fertility. In addition, the presence of $\mathrm{C}$ in amorphous element oxides creates a similar positive effect in the soil.

Table 5- The minerals observed in the BCs

\begin{tabular}{cccc}
\hline Characteristic Peaks $(\hat{A})$ & Minerals & Abbreviations & BCs \\
\hline 3.41 & Quartz & Q & PLBC \\
$3.91 ; 3.40 ;$ & Cristobalite & Crb & RHBC \\
$3.96 ; 2.94 ; 1.91$ & Calcite & Ca & PLBC \\
$3.06 ; 1.85$ & Sylvine & Syl & PLBC \\
$278 ; 2.17$ & Whitlockite & Wh & PLBC \\
- & Amorphous Carbon & AC & TWBC \\
$4.02 ; 2.97$ & Amorphous silica & AS & HHBC \\
\hline $2.34 ; 2.33 ; 1.94 ; 1.92 ; 1.42 ; 1.41 ;$ & \multirow{2}{*}{ Partially crystallized carbon } & \multirow{2}{*}{ CryC } & HHBC \\
$2.30 ; 1.94 ; 1.41 ; 1.20$ & & RHBC \\
\hline
\end{tabular}

TWBC: Tea waste biochar; HHBC: Hazelnut husk biochar; RHBC: Rice husk biochar; PLBC: Poultry litter biochar

The XRD diagrams of the plant-derived BCs (i.e., HHBC and RHBC) were found to be similar (see Table 5 and Figure 1). In HHBC and RHBC, partially crystallized carbon (CryC) peaks were mainly observed between 1.20 and 2.34 ( $)$, and cristobalite peaks (i.e., amorphous $\left.\mathrm{SiO}_{2}\right)$ in 3.91 and $3.40(\AA)$. In addition, small amounts of calcite and sylvine, as well as minerals such as CryC and cristobalite, were detected. 
Qadeer et al. (1994) showed that the diffractogram obtained from an XRD analysis of a RH was amorphous but confirmed that it had some local crystal structure, with highly conjugated aromatic compounds. Other researchers have stated that the gaps in the range of $5.8 \AA$ and $3.89 \AA$-indicating the crystalline structure of cellulose in the rice-can be defined at pitch intervals of $6.0 \AA, 5.8 \AA, 4.44 \AA, 4.04 \AA, 3.89 \AA, 2.52 \AA$ and $3.89 \AA$ (Keiluweit et al. 2010; Al-Wabel et al. 2013). In the XRD diffractogram in the present study, TWBC, which did not show a crystalline peak, can be said to be an amorphous $\mathrm{C}$ structure, possibly consisting of randomly ordered aromatic $\mathrm{C}$ layers. HHBC had a different structure than did the other materials, with an amorphous structure as well as Si and C content.

The chemical and spectroscopic properties of the BCs differed depending on the feedstock used to create them. Compared to the characteristics derived by the pyrolysis of different materials at the same temperature, PLBC, which is derived from manure, has better properties in terms of its elemental content and specific surface area when compared to those of plant-derived BCs. However, it was not superior in terms of $\mathrm{pH}$. This is because this material contains a high mineral fraction, the most basic indicator of which is its high ash content and low $\mathrm{C}$ content. The arsenic (As) content of PLBC was found to be quite low. Because $\mathrm{N}$ is lost during pyrolysis, the $\mathrm{N}$ content is also quite low. Furthermore, it is not rich in Ca or P. This is similar to what was found in BCs obtained from plant base materials. However, the high salt content of PLCB should be taken into consideration when using it. It was seen that an amorphous structure is formed as a result of the burning of $\mathrm{C}$ in plant-derived BCs. While partly CryC was observed in RHBC and $\mathrm{HHBC}$, amorphous $\mathrm{C}$ was found to be prominent in TWBC; this $\mathrm{C}$ was recalcitrant. It was also seen that RHBC, a plant-derived $\mathrm{BC}$, is richer in terms of microelements - and especially of Co and $\mathrm{Zn}-\mathrm{when}$ compared to other BCs.

\section{Conclusions}

Among the BCs reviewed in this study, PLBC was found to be preferable for use in agriculture as a source of plant nutrients. RHBC can be used as a source of Si to obtain silica for various purposes. BCs with a high pH value can be used to regulate the $\mathrm{pH}$ level in acidic soils. However, whether it is necessary to convert all plant waste into BC should be discussed further, as the high energy cost required for pyrolysis must be compared with the benefits and economic returns of producing BC. Therefore, researchers should study BC made with the same or different materials in different regions and should classify them into groups according to their suitability in various fields, such as those of agronomics, industry and energy. The overall benefit of BC could be better understood if a database was established that clearly shows which material can be used for which purpose. In this way, researchers working in multidisciplinary fields could select the appropriate $\mathrm{BC}$ from the database and use it for its ideal purposes. Feedstocks can be transformed into suitable BC material, according to its intended use, by designing the chemical structure of the $\mathrm{BC}$ before pyrolysis. Identifying and cataloguing the characteristics of various BCs will allow researchers to gain easy access to information about the BCs that are ideal for certain intended uses. As such, it is thought that studies such as this one will contribute to the establishment of a database of BCs and their potential uses. It has been seen that spectroscopic methods (e.g., XRF and XRD spectroscopy) can be used to determine the mineral content and structure of BCs quickly and at low cost. Studies on $\mathrm{BC}$ reveal the necessity of using spectroscopic methods due not only to their speed and low cost but also to their analytical reliability and more accurate results.

\section{Acknowledgements}

The authors are grateful to the Earth Sciences Application and Research Centre (YEBIM) of Ankara University for the use of the laboratory facility.

\section{References}

Ahmad F, Khan A U \& Yasar A (2013). Transesterification of oil extracted from different species of algae for biodisel production. Afr. $J$ Environ Sci Technol 7(6):358-64 https://doi.org/10.5897/AJEST12.167

Al-Wabel M I, Al-Omran A, El-Naggar A H, Nadeem M \& Usman A R A (2013). Pyrolysis temperature induced changes in characteristics and chemical composition of biochar produced from conocarpus wastes. Bioresour. Technol 131: 374-379 https://doi.org/10.1016/j.biortech.2012.12.165

Apaydın-Varol E \& Pütün A E (2012). Preparation and characterization of pyrolytic chars from different biomass samples. Journal of Analytical and Applied Pyrolysis 98: 29-36 https://doi.org/10.1016/j.jaap.2012.07.001

Armynah B, Djafar Z, Piarah W H \& Tahir D (2018). Analysis of chemical and physical properties of biochar from rice husk biomass. In Journal of Physics: Conference Series (Vol. 979, No. 1, p. 012038). IOP Publishing

ASTM D1762-84 (2007). Standard test method for chemical analysis of wood charcoal. Conshohocken, PA: American Society for Testing and Materials

Beesley L, Moreno-Jimenez E, Gomez-Eyles J L, Harris E, Robinson B \& Sizmur T (2011). A review of biochars' potential role in the remediation, revegetation and restoration of contaminated soils. Environ Pollut 159: 474-480 https://doi.org/10.1016/j.envpol.2011.07.023

Bellon-Maurel V \& McBratney A (2011). Near-infrared (NIR) and mid-infrared (MIR) spectroscopic techniques for assessing the amount of carbon stock in soils-Critical review and research perspectives. Soil Biology and Biochemistry 43(7): 1398-1410 https://doi.org/10.1016/j.soilbio.2011.02.019

Bintaş E, Bozkurt M, Küçükyılmaz K, Konak R, Çınar M, Akşit H, Seyrek S \& Çatlı A U (2014). Efficacy of Supplemental Natural Zeolite in Broiler Chickens Subjected to Dietary Calcium Deficiency. Italian Journal of Animal Science 13: 3141 275-283 https://doi.org/10.4081/ijas.2014.3141 
Bourke J, Manley-Harris M, Fushimi C, Dowaki K, Nunoura T \& Antal M J (2007). Do all carbonized charcoals have the same chemical structure? 2. A model of the chemical structure of carbonized charcoal. Industrial \& Engineering Chemistry Research 46(18): 5954-5967 https://doi.org/10.1021/ie070415u

Bremner J M (1965). Total nitrogen. Agronomy 9: 1149-78 https://doi.org/10.2134/agronmonogr9.2.c32

Brunauer S, Emmett P H \& Teller E (1938). Adsorption of Gases in Multimolecular Layers. J Am Chem Soc. 60(2): 309-319 https://doi.org/10.1021/ja01269a023

Cabrera A, Cox L, Spokas K A, Celis R, Hermosín M C, Cornejo J \& Koskinen W C (2011). Comparative sorption and leaching study of the herbicides fluometuron and 4- chloro-2 methylphenoxyacetic acid (MCPA) in a soil amended with biochars and other sorbents. J. Agri. Food Chem 14: 12550-12560 https://doi.org/10.1021/jf202713q

Chan K Y \& Xu Z (2009). Biochar: nutrient properties and their enhancement. In: Lehmann J, Joseph S, editors. Biochar for Environmental Management Science and Technology. Earthscan, London pp. 67-8. https://doi.org/10.4324/9781849770552

Chan K Y, Van Zwieten L, Meszaros I, Downie A \& Joseph S (2007). Agronomic values of greenwaste biochar as a soil amendment. Aust. J. Soil Res 45: 629-634 https://doi.org/10.1071/SR07109

Clemente J S, Beauchemin S, Thibault Y, MacKinnon T \& Smith D (2018). Differentiating Inorganics in Biochars Produced at Commercial Scale Using Principal Component Analysis. ACS Omega 3: 6931-6944 https://doi.org/10.1021/acsomega.8b00523

DeLuca T H (2009). Nutrient imbalances: follow the waste. Science 326(5953): 665-665 https://doi.org/10.1126/science.326_665a

Downie A, Crosky A \& Munroe P (2009). Physical properties of biochar. In 'Biochar for Environmental Management: Science and Technology'. (Eds J Lehmann, S Joseph) pp. 13-32 (Earthscan, London, UK)

El-Naggar A, El-Naggar A H, Shaheen S M, Sarkar B, Chang S X, Tsang D C \& Ok Y S (2019). Biochar composition-dependent impacts on soil nutrient release, carbon mineralization, and potential environmental risk: a review. Journal of environmental management 241: 458467 https://doi.org/10.1016/j.jenvman.2019.02.044

Enders A, Hanley K, Whitman T, Joseph S \& Lehmann J (2012). Characterization of biochars to evaluate recalcitrance and agronomic performance. Bioresour Technol 1: 114: 644 https://doi.org/10.1016/j.biortech.2012.03.022

European Biochar Certificate [EBC] (2015). Guidelines for a Sustainable Production of Biochar. European Biochar Foundation (EBC), Arbaz, Switzerland

Evans M R, Jackson B R, Popp M \& Sadaka S (2017). Chemical Properties of Biochar Materials Manufactured from Agricultural Products Common to the Southeast United States. HortTecnology 27(1) https://doi.org/10.21273/HORTTECH03481-16

Fang Z \& Xu C B (2014). Near-critical and supercritical water and their applications for biorefineries. Dordrecht: Springer. https://doi.org/10.1007/978-94-017-8923-3

Field J L, Keske C M, Birch G L, DeFoort M W \& Cotrufo M F (2013). Distributed biochar and bioenergy coproduction: a regionally specific case study of environmental benefits and economic impacts. Gcb Bioenergy 5(2): 177-191 https://doi.org/10.1111/gcbb.12032

Glaser B, Parr M, Braun C \& Kopolo G (2009). Biochar is carbon negative. Nat. Geosci 2(1): 2. https://doi.org/10.1038/ngeo395

Gunarathne V, Mayakaduwa S \& Vithanage M (2017). Biochar's Influence as a Soil Amendment for Essential Plant Nutrient Uptake. In: Naeem M, Ansari, Gill S. (eds) Eseential Plant Nutrients. Springer, Cham. https://doi.org/10.1007/978-3-319-58841-4_3

Güllü B \& Kadığlu Y K (2017). Use of tourmaline as a potential petrogenetic indicator in the determination of host magma: CRS, XRD and PED-XRF methods. Spectrochimica Acta Part A: Molecular and Biomolecular Spectroscopy 183: 68-74. https://doi.org/10.1016/j.saa.2017.04.032

Hammes K, Schmidt M W, Smernik R J, Currie L A, Ball W P, Nguyen T H \& Cornelissen G (2007). Comparison of quantification methods to measure fire-derived (black/elemental) carbon in soils and sediments using reference materials from soil, water, sediment and the atmosphere. Global Biogeochemical Cycles 21(3) https://doi.org/10.1029/2006GB002914

Igalavithana A D, Lee S E, Lee Y H, Tsang D C, Rinklebe J, Kwon E E \& Ok Y S (2017). Heavy metal immobilization and microbial community abundance by vegetable waste and pine cone biochar of agricultural soils. Chemosphere 174: 593-603 https://doi.org/10.1016/j.chemosphere.2017.01.148

Jassal R S, Johnson M S, Molodovskaya M, Black T A, Jollymore A \& Sveinson K (2015). Nitrogen enrichment potential of biochar in relation to pyrolysis temperature and feedstock quality. J Environ Manage 1(152): 140-4 https://doi.org/10.1016/j.jenvman.2015.01.021

Kadıŏlu Y K, Üstündağ Z, Deniz K, Yenikaya C \& Erdoğan Y (2009). XRF and Raman Characterization of Antimonite. Instrumentation Science and Technology 37: 683-696 https://doi.org/10.1080/10739140903252956

Keiluweit M, Nico P S, Johnson M G \& Kleber M (2010). Dynamic molecular structure of plant biomass-derived black carbon (biochar). Environmental Science \& Technology 44: 1247-1253 https://doi.org/10.1021/es9031419

Kim W K, Shim T, Kim Y S, Hyun S, Ryu, C, Park Y K \& Jung J (2013). Characterization of cadmium removal from aqueous solution by biochar produced from a giant Miscanthus at different pyrolytic temperatures. Bioresource technology 138: 266-270 https://doi.org/10.1016/j.biortech.2013.03.186

Koralay T (2010). Petrographic and geochemical characteristics of upper Miocene Tekkedag volcanics (CentralAnatolia-Turkey). Chemie der Erde 70: 335-351 https://doi.org/10.1016/j.chemer.2010.03.002

Kuo S (1996) Phosphorus. In: Sparks, D.L., Ed., Methods of Soil Analysis: Part 3, SSSA Book Series No. 5, SSSA and ASA, Madison, 869919 https://doi.org/10.2136/sssabookser5.3.c32

Lehman J, Gaunt J \& Rondon M (2006). Biochar sequestration in terrestial ecosystems. A review. Mitig. Adapt. Strateg. Glob. Change 11(2): 403-427 https://doi.org/10.1007/s11027-005-9006-5

Lehmann J \& Joseph S (2015). Biochar for environmental management: an introduction. In: Biochar for environmental management: science, technology and implementation. Taylor and Francis, London pp. 1-13 https://doi.org/10.4324/9780203762264

Li X, Shen Q, Zhang D, Mei X, Ran W, Xu Y \& Yu G (2013). Functional groups determine biochar properties (pH and EC) as studied by twodimensional ${ }^{13} \mathrm{C}$ NMR correlation spectroscopy. PLoS One 8(6). https://doi.org/10.1371/journal.pone.0065949.g001

Nakka S B R (2015). Biocharculture: Biochar for environment and development. ASIN: B01FJUPYCO

Ogawa M, Okimori Y \& Takahashi F (2006). Carbon sequestration by carbonization of biomass and forestation: Three case studies. Mitig. Adapt. Strateg. Glob. Change 11: 429-444 https://doi.org/10.1007/s11027-005-9007-4

Prakongkep N, Gilkes R J \& Wanpen W (2015). Forms and solubility of plant nutrient elements in tropical plant waste biochars. Journal of Plant Nutrition and Soil Science 178(5) https://doi.org/10.1002/jpln.201500001

Qadeer R, Hanif J, Saleem M \& Afzal M (1994). Characterization of activated-charcoal. J. Chem. Soc. Pak 16(4): 229-235 
Qambrani N A, Rahman M M, Won S, Shim S, \& Ra C (2017). Biochar properties and eco-friendly applications for climate change mitigation, waste management, and wastewater treatment: A review. Renewable and Sustainable Energy Reviews 79: 255-273 https://doi.org/10.1016/j.rser.2017.05.057

Rajkovich S, Enders A, Hanley K, Hyland C, Zimmerman A R \& Lehmann J (2012). Corn growth and nitrogen nutrition after additions of biochars with varying properties to a temperate soil. Biology and Fertility of Soils 48(3): 271-284 https://doi.org/10.1007/s00374-0110624-7

Rayment G E \& Higginson F R (1992). Australian Laboratory Handbook of Soil and Water Chemical Method. Reed International Books Australia P/L, Trading as Inkata Press, Port Melbourne $330 \mathrm{p}$

Scott H, Ponsonby D J \& Atkinson C J (2014). Biochar: An improver of nutrient and soil water availability-what is the evidence? CAB Reviews 9, No. 01. CAB Reviews Perspectives in Agriculture Veterinary Science Nutrition and Natural Resources 9 https://doi.org/10.1079/PAVSNNR20149019

Sikder S \& Joardar J C (2019). Biochar production from poultry litter as management approach and effects on plant growth. Int J Recycl Org Waste Agricult 8: 47 https://doi.org/10.1007/s40093-018-0227-5

Singh B, Singh B P \& Cowie A L (2010). Characterisation and evaluation of biochars for their application as a soil amendment. Soil Research 48(7): 516-525 https://doi.org/10.1071/SR10058

Suliman W, Harsh J B, Abu-Lail N I, Fortuna A M, Dallmeyer I \& Garcia-Perez M (2016). Influence of feedstock source and pyrolysis temperature on biochar bulk and surface properties. Biomass and Bioenergy 84: 37-48 https://doi.org/10.1016/j.biombioe.2015.11.010

Tamai K \& Feng Ma J (2003). Characterization of silicon uptake by rice roots. New Phytologist 158(3): 431-436 https://www.jstor.org/stable/1514103

Tang J, Zhu W, Kookana R \& Katayama A (2013). Characteristics of biochar and its application in remediation of contaminated soil. J Biosci Bioeng 116(6): 653-9. https://doi.org/10.1016/j.jbiosc.2013.05.035

Verheijen F, Jeffery S, Bastos A C, van der Velde M \& Diafas F (2010). Biochar application to soils. A critical scientific review of effects on soil properties, processes, and functions. EUR 24099 EN Office for the Official Publications of the European Communities, Luxembourg, 149 p https://doi.org/10.2788/472

Wang M, Wang J J \& Wang X (2018). Effect of KOH-enhanced biochar on increasing soil plant-available silicon. Geoderma, 321: 22-31 https://doi.org/10.1016/j.geoderma.2018.02.001

Wilding L P, Brown R E \& Holowaychuk N (1967). Accessibility and Properties of Occluded Carbon in Biogenic Opal. Soil Science 103: 5661

Xu Y \& Chen B (2013). Investigation of thermodynamic parameters in the pyrolysis conversion of biomass and manure to biochars using thermogravimetric analysis. Bioresource technology, 146: 485-493 https://doi.org/10.1016/j.biortech.2013.07.086

Zhao B \& Nartey O D (2014). Characterization and evaluation of biochars derived from agricultural waste biomass from Gansu, China *, the 2014 world congress on Advances on civil, environmental, and materials research (ACEM 14), Busan, Korea, August, 24-28, 2014 https://doi.org/10.1155/2014/715398

Zhao L, Cao X, Mašek O \& Zimmerman A (2013). Heterogeneity of biochar properties as a function of feedstock sources and production temperatures. Journal of hazardous materials 256:1-9 https://doi.org/10.1016/j.jhazmat.2013.04.015

(c) 2021 by the authors. Licensee Ankara University, Faculty of Agriculture, Ankara, Turkey. This article is an open access article distributed under the terms and conditions of the Creative Commons Attribution (CC BY) license (http://creativecommons.org/licenses/by/4.0/). 